\title{
SOCIAL CAPITAL, SUPPORT NETWORKS AND BLACK ELDERLY PERSONS
}

\section{F Howes}

\section{INTRODUCTION}

The Department of Social Services and Poverty Alleviation in the Western Cape sees itself as the lead Department for social capital formation. (Department of Social Services and Poverty Alleviation, 2005:5). The said Department accepts the following definition of social capital: "Social capital refers to the strengthening and establishment or networks, relationships, norms and values that contribute to the building of social cohesion, racial integration and the strengthening of a social safety net during times of crisis (economic, natural and other). It is not an end in itself, but a means to an end" (Department of Social Services and Poverty Alleviation, 2005:23). Putnam (2000:19) makes the following statement: "social capital refers to connections among individuals - social networks and the norms of reciprocity and trustworthiness that arises from them. In that sense social capital is closely related to what some have called 'civic virtue'. The difference is that 'social capital' calls attention to the fact that civic virtue is most powerful when embedded in a dense network of reciprocal social relations. A society of many virtuous but isolated individuals is not necessarily rich in social capital." Social capital is thus of pivotal importance in the provincial and national agenda of fostering social cohesion and social inclusiveness.

Demographic trends indicate that older black people are living longer and as a result they may experience greater levels of disability than previously. There is, however, a severe lack of formal services, i.e. senior services centres, senior housing facilities and old age homes, with the result that informal support networks play a crucial role in this respect. A situation analysis by the Department of Social Services and Poverty Alleviation (2005:27) of the position of the aged in the Western Province reported that the services for the aged are fragmented, and that a lack of transport services hampers access to services. This results in racially biased services. Integration of the elderly in the existing services is often restricted because of the distance of the service centre from marginalised communities. Until this situation changes, black elderly persons have to rely on their support networks. However, their support networks have diminished due to greater female employment, the erosion that AIDS has caused in the black female population, and the greater geographic mobility as a result of the abolition of group areas legislation.

It is against this background that the present research was undertaken in Kayamandi, a predominantly black residential area of Stellenbosch.

\section{PROBLEM STATEMENT}

Social capital as a social science concept has gained prominence in recent years. Also the World Bank considers social capital as important and views social capital and human capital as generally complementary (Field, 2003:9). It was Robert Putnam (2000) who drew attention to the sizable decline of social capital since the 1940s. This decline manifested itself in political participation; associated membership; religious participation; volunteer work; charity work; work-based socializing and informal social networks. This new interest in social capital, i.e. social networks, brought about an interest in the pay-offs that arise from relationships. According to Field (2003:45), people who are able to draw on others for support are healthier 
than those who cannot; they are also happier and wealthier; their children do better at school, and their communities suffer less from anti-social behaviour.

Woolcock (in Field, 2003:42) makes the following distinction between different types of social capital:

"(a) bonding social capital, which denotes ties between like people in similar situations, such as immediate family, close friends and neighbours;

"(b) bridging social capital, which encompasses more distant ties of like persons, such as loose friendships and workmates; and

“(c) linking social capital, which reaches out to unlike people in dissimilar situation such as those who are entirely outside the community thus enabling members to leverages far wider range of resources than are available within the community."

Social capital can be considered the infrastructure of society - the vital forces that link, hold and consolidate actors and organisations in society (Lin, 2001:186). Flap (in Lin, 2001:21) specifies three elements of social capital: (1) the number of persons within one's social network who "are prepared or obliged to help you when called upon to do so"; (2) the strength of the relationship indicating readiness to help; and (3) the resources of these persons.

It is laudable that social capital forms the cornerstone of the social welfare policy of the Western Cape. The majority of communities that have been socially marginalised are divided along ethnic and/or religious lines; are in a state of chronic and inter-generational poverty; and are accommodating an influx of relocating people. Communities like this are usually high in anomie, alienation and normlessness, and low in social capital.

Interpersonal relationships and the social networks that result from these relationships have always been one of the focal points of social work. The ecological perspective in social work increased the awareness of a person environment fit. Through transactions a person is linked to his/her environment and these transactions between individuals, systems and institutions in the environment form a social network around the person (Howes \& Green, 1996:32). Pattison and Hurd (in Howes \& Green, 1996:32) define a social network as the entirety of social links between persons in a finite community of relationships. It is the sum total of a person's relationships with others. Embeddedness in a social network influences a person's behaviour and fosters a connectedness with others in the social milieu (Howes \& Green, 1996:32).

Tracy and Whittaker (1990:462) claim that social networks have structural and functional characteristics. Structural characteristics include:

- size of the network, i.e. the number of persons with whom the individual is in regular contact;

- the density of the network, i.e. the individual is not involved in only one network, but in several interrelated networks;

- geographical proximity, i.e. the distance that persons in the network are removed from each other and that determines the nature and quality of the interaction in the network; and

- multiplexity, i.e. relationships can overlap; can be one-directional or involve several different roles.

The functional characteristics include:

- social embeddedness, i.e. a social network integrates a person in a social milieu; gives the person a sense of belonging and combats alienation and social isolation; 
- a barrier against stress, i.e. a social network is a defence mechanism that helps a person to handle stress and to increase a person's coping ability;

- social feedback, i.e. the social network gives feedback on behaviour and can enhance the person's self-image and self-worth and, by offering an opportunity to test new social skills, can increase the person's social functioning;

- assistance, i.e. tangible and material assistance but also imparting knowledge, either directly or laterally (Howes \& Green, 1996:32-33).

It is the functional characteristics of a social network that make it a support system, i.e. "a set of relationships that provide nurturance and reinforcement for coping with life on a daily basis" (Sheafor, Horejsi \& Horejsi, 1994:224). To be effective a support system has to be available; has to be acceptable for the person, and the person should have the necessary social skills to access the support system. When utilised correctly, a support system can enhance a person's coping ability. According to Warren (1981:11), coping entails the mobilisation and utilisation of the supports, skills and assistance available in a person's social network for dealing with and solving problems. Social support is the perception of emotional sustenance, informational guidance and tangible assistance (Holahan, Moos, Holahan \& Brennan, 1996:36).

The position of black elderly persons has to be viewed against a specific background. Referring to American black elderly persons, Beaver and Miller (1992) argue that older black people are among the most disadvantaged groups in society. By virtually any standard of measurement their quality of life is below that of the majority of older Americans. The said authors state that as a group, older black people have experienced more social, economic and psychological damage than any other group, primarily because of de jure and de facto racial discrimination. Even in old age they still find themselves in a disadvantaged position. This argument is also true for black elderly persons in South Africa.

In addition to this disadvantaged position there is also a cultural aspect. Norton (1978) first coined the term 'dual perspective' to explain the position of individuals who have been marginalised and operating in two systems. He describes the two systems as the nurturing system, which includes the family and immediate community environment and culture of an individual, and the sustaining system, which includes the organisation of goods and services, political power, economic resources, educational system and larger societal systems. According to this perspective, if there are broad areas of incongruence between the two systems, then individuals are prone to experience difficulties in their social functioning" (Norton, 1978:3). Adaptation in this bicultural situation requires coping patterns and social skills to overcome the environmental unresponsiveness and to avoid stress. Stress, according to Germain and Gitterman (1980:7), is the psychosocial condition generated by discrepancies between needs and capacities, on the one hand, and environmental qualities, on the other hand. The same authors state that stress arises in three interrelated areas of living: life transitions, negotiations with the environment and interpersonal processes (Germain \& Gitterman, 1980:7).

Superimposed on the challenges of the "dual perspective" are the demands of old age. Growing old is a life transition that necessitates coping skills. Old age is accompanied by declining physical ability and health; the loss of a life partner, family and friends; and changes in economic status. This state of affairs has resulted in what the Americans have termed "double jeopardy" (Kart, 1985:360). This implies that minority-group members suffer both old 
age and race discrimination. Tally and Kaplin (in Hooyman \& Kiyak, 1991:462) raised the question: "Are the African American aged doubly jeopardized relative to their white counterparts? That is, do lifetime factors of economic and racial discrimination make adjusting to old age more difficult for African Americans (and other minorities) than for whites?"

The present cohort of South African black elderly people undoubtedly experienced the double jeopardy. They are too old to experience the benefits of the new South Africa and they are not considered a priority in the allocation of formal services. The high incidence of HIV/AIDS and crimes of violence often result in grandparents having to accept the responsibilities of parenthood out of necessity. This brings about new challenges and hardship for black elderly people. The negative effects of aging are compounded for this sector of the population.

\section{METHODOLOGY}

Although there are many assumptions about the social networks of black elderly persons, these assumptions have not been verified. An exploratory study was undertaken "to gain insight into a situation, phenomenon, community or individual" (DeVos, Strydom, Fouche \& Delport, 2002:109) and to become acquainted with a situation.

The study was conducted in Kayamandi, the predominantly black residential area of Stellenbosch. This residential area was established in 1941 and the Black population group was gradually relocated here. An inhabitant, Doreen Matyatya, describes it as follows (free translation by author): "When I arrived here in 1955, there were only a few houses, about 118 three-roomed houses that we rented from the Municipality. Although the houses were very small, we were quite proud of these houses. There was one bedroom, a kitchen and a dining room. The toilet and water tap were outside and at night we often had to go to the toilet by candle light, which of course was very uncomfortable... The yard around the house was very clean and tidy and my mother often won prizes for the prettiest garden. Later, when the houses became too small, the Municipality built shanties (pondokkies), which of course damaged the image of the place.... There were also different hostels where the migrant labourers lived. The hostels were rather dirty, but the Municipality conducted regular inspections to ensure that there were no outbreaks of disease.... That time there was poverty but not as widespread as today" (Biscombe, 2006:xxiv). In recent times informal housing has increased considerably and the destruction of these constructions by fire forced the local authority to built transit housing for the victims of these fires. Kayamandi does not have any shops, pharmacies or banks, and the residents have to go into Stellenbosch to conduct their business.

In 2006 the population of Stellenbosch was 116 606, of whom 28,3\% live in rural areas and $71,7 \%$ live in an urban area. The population is predominantly coloured $(57,3 \%)$, with whites $(21,9 \%)$ and blacks $(20,8 \%)$ relatively evenly split (Cape Winelands District Municipality, 2006:67.)

According to the 2001 census, the total population of Kayamandi is 14,254 and the persons over 65 total 222 (Stellenbosch Municipality Integrated Development Plan, 2006:5).

Initially visits were made to the area to determine the resources available in the area and to get acquainted with the layout of the area. Through observation valuable data were gained about the living conditions in the area.

Through the clinic in the area, an elderly lady who did voluntary work amongst the elderly was identified. This lady accompanied the researcher on home visits to seven elderly persons. This pilot study was undertaken to (a) gain insight into the living conditions of the elderly; (b) 
determine whether the respondents would co-operate and be prepared to be interviewed; (c) find out whether the respondents could communicate in English or Afrikaans; and (d) gauge the appropriateness of the data collection instruments. All the respondents were willing to be interviewed and could communicate in English or Afrikaans. These seven respondents were not included in the research group.

Snowball sampling (De Vos, Strydom, Fouche \& Delport, 2002:336) was accepted as suitable for this study. In December 2005 the researcher visited the pension/grant payout point is Kayamandi. One lady recipient of an old-age pension was interviewed and accompanied the researcher to the houses of other elderly people. It was agreed that they would get together at a specific venue in February 2006. At the first meeting the purpose and nature of the study was explained and it was arranged that the researcher would be at the venue two days a week to do the interviews. Every week one or two respondents were interviewed and the final interview was conducted in June. The research group consisted of 17 respondents.

Data collection was done with an interview schedule and a social network grid. The interview schedule consisted of closed questions to obtain demographic data and open questions to gain subjective data. The social network grid was adapted from the social network grids of Tracy and Whittaker (1990:466) and Sheafor et al. (1994:226-228). It was necessary to adapt the social network grid because the original grids were intended for clinical practice and not for research purposes or an elderly research group.

The researcher personally did all the interviews and this ensured uniformity. Each interview lasted between 45 to 60 minutes. The qualitative data were analysed around categories to determine tendencies. Observational data were used to supplement other data.

\section{FINDINGS AND DISCUSSION}

The collected data revealed the following demographic information:

\section{Marital status}

Marital status is depicted in the following table:

TABLE 1

MARITAL STATUS

\begin{tabular}{|l|c|}
\hline Married & 6 \\
Widowed & 10 \\
Separated & 1 \\
\hline TOTAL & $\mathbf{1 7}$ \\
\hline
\end{tabular}

The age and gender of the research group are depicted in the following table:

TABLE 2

AGE AND GENDER

\begin{tabular}{|c|c|c|}
\hline $60-65$ & 1 male & 8 female \\
$66-70$ & 1 male & 3 female \\
$71-75$ & 0 male & 3 female \\
$76-80$ & 1 male & 0 female \\
\hline TOTAL & $\mathbf{3}$ male & $\mathbf{1 4}$ female \\
\hline
\end{tabular}


182

The research group consisted mostly of young elderly, i.e. between 60 and 65 years, and females dominated the group 4:1. The research group does not reflect the profile of the elderly population in Kayamandi. For this population the over-65 age cohort males total 114 and females 108 (Stellenbosch Municipality Integrated Development Plan, 2006:5) and a male/female split of 59/41\% (Cape Winelands District Municipality, 2006:81).

\section{Children}

The number of children ranged from eight to two, with an average of four children. Several respondents have lost children, e.g. one respondent had twelve children, but there are only two surviving children; one had six deceased children and two respondents had two deceased children. The accuracy of the response to this question was influenced by the Xhosa custom that illegitimate children of a daughter belong to the grandparents and are treated as such, even calling the grandparents "father" and "mother".

\section{Language}

The majority of the research group was bilingual and one respondent could speak only isiXhosa. Five respondents could speak isiXhosa and English; four isiKhosa and Afrikaans; three isiXhosa, Afrikaans and a little English; and four isiXhosa, Afrikaans and English. isiXhosa is the language of $94,8 \%$ of the inhabitants of Kayamandi, Afrikaans 3,4\% and English 0,18\% (Stellenbosch Integrated Development Plan, 2006:8).

\section{Education}

The educational level of the respondents is depicted in the following table:

TABLE 3

EDUCATIONAL LEVEL

\begin{tabular}{|l|c|}
\hline Illiterate & 2 \\
\hline Std 1 (Grade 3) & 2 \\
Std 2 (Grade 4) & 1 \\
Std 4 (Grade 6) & 3 \\
Std 6 (Grade 8) & 5 \\
Std 7 (Grade 9) & 3 \\
Std 8 (Grade 10) & 1 \\
\hline TOTAL & 17 \\
\hline
\end{tabular}

Two respondents $(11,7 \%)$ were illiterate and never attended school. Two respondents who reached Std 1 (Grade 3) have been attending literacy classes at the local library for the past two years. According to them, there are several people from Kayamandi attending these classes. Of the research group 35,2\% had some primary school education, and $29,4 \%$ completed primary school. Only $23,5 \%$ of the research group had secondary school education. When this age cohort went to school, they could only attend primary school locally and after that they had to go to the then homelands to attend secondary school. The cost that this entailed put it beyond the reach of many people. The one respondent who passed Std 8 (Grade 10) went to nursing college and was a nurse at a local hospital for 36 years.

\section{Economic aspects}

The majority of the respondents depended on an old-age pension (OAP); in seven cases a single pension and in two cases two pensions. One of the respondents had only a private pension. Three of the respondents had an OAP plus a private pension, while two respondents 
had OAP plus provident fund income. Two married respondents had salaries plus provident fund income and OAP.

Some of the respondents reported financial hardship. One of the fire victims, who was presently living in temporary housing, has a school-going daughter in Grade 12. Her two sons live in a shack; both are unemployed and one also has TB. She said that she depends on welfare organisations to help her financially. She also goes to a soup kitchen. As most households have extended families they often pool resources or contribute in kind, e.g. buy food, etc. Several of the respondents have unemployed adult children living with them and thus have to support their adult children. In his research Strydom (2001) found that serious financial problems dominated all other problems that older people face. This was also found in the research group.

\section{HOUSING AND LIVING ARRANGEMENTS}

\section{Type of housing}

One respondent lived in a two-roomed shack with her daughter and partner and four grandchildren. The majority of respondents (13) were homeowners and three lived in temporary accommodation. These three persons were the victims of a fire that destroyed their informal housing and the Municipality provided them with temporary accommodation (tworoomed houses) until they can be provided with permanent housing. One respondent's story is very typical: her husband came here in 1970. She came for shorter periods to visit him, but in 1984 came here to settle. Initially they lived in the hostel, but in 1990 they built their own shack. Her husband died and in 1998 her shack burnt down. She rebuilt it, but it burned down a second time. In 2006 she and her daughter were allocated a temporary house.

The fact that the majority of the respondents were home owners and live in formal housing is an indication of their embeddedness in the community. Only one respondent lived in informal housing. This is remarkable, because informal houses outnumber formal houses in Kayamandi. There are 812 formal houses and 2304 informal units in Kayamandi (Stellenbosch Municipality Integrated Development Plan, 2006:9).

Because of the shortage of housing, most houses have other structures on the same site. Nghatsane (1992:179) found that the majority of his respondents had structures built next to their houses, which were used to accommodate their children or family, or rented out to other people. The present research found the same situation in Kayamandi. (In the pilot study one formal house had two other wooden structures on the site and in total 28 people lived there.) Two of the respondents were planning additions to their houses, which they intend renting out, especially to students.

\section{Living arrangements}

The majority of the households consisted of three generations and, in the case of two households, four generations. Ten households had grandchildren living with the elderly person. In several of these cases the elderly person had full responsibility for these children, e.g. the son had an illegitimate child and the birth mother brought the child to the grandparents; one daughter left her children with the grandparents and disappeared; one widow is caring for four orphaned grandchildren. (The mother of two of these children went to Gauteng with her boyfriend. The boyfriend later informed the widow that her daughter had died. However, as she does not have the necessary documents, she cannot apply for a foster grant for the children.) Mokone's (2006) research found that daughters went away and never came back; that the biological parents were not involved in the upbringing of their children; and that 
grandparents have to parent their grandchildren out of necessity. Three households had only a parent(s) and their children, and two respondents had only grandchildren living with them.

\section{Duration of residence}

Only two respondents have been in their present home for less than a year and they were both re-housed after their shacks were destroyed by fire. Eight respondents have resided less than 10 years in their homes - three of these because they received so-called RDP houses. The remaining seven respondents have resided in their present houses 11-20 years (2); 21-30 years (2); 31-40 years (1); and 41+ years (2). Some of the respondents grew up in this residential area. Nghatsane (1992:157) found in his research in three black residential areas of Cape town that elderly people have lived in the area for a long time, which he considered unexpected because of the assumption that black people in the Western Cape were migrant workers. In his research he found that of his research group $48 \%$ had lived in the Cape Peninsula for more than 30 years; $12,3 \%$ had lived there $25-30$ years; and 9,4\% had lived there less than 10 years.

\section{View of neighbourhood}

The respondents' view of their neighbourhood varied. The long-time residents stated that they liked their neighbourhood, but resented the changes that have taken place, e.g. influx of "inkommers"; the increase in shebeens; rising drug abuse and crime; shacks being erected on all open spaces, etc. Respondents said that unemployed persons frequented the shebeens and became rowdy and involved in fights. The respondents who have not been living in the area for a long time were more negative and mentioned that the area was dirty; had overflowing drains; and also that they did not socialise much. One respondent reported that she was born in Stellenbosch and her parents moved to Kayamandi when she was 9 years old. She likes it there ("This is my place" - "dis mos my plek"). She says that Snake Valley is where the 'rough' people live and where crime is rife. She has never been to Snake Valley.

\section{Health issues and caretaking}

Only one of the respondents was totally dependent on others, because she cannot walk and is chair bound. Four were partially dependent because of poor eyesight (diabetes). The chronic conditions that the respondents suffer from and take medication for is as follows: high blood pressure and diabetes (7); high blood pressure (2); diabetes (2); blood pressure and asthma (1); blood pressure and heart (1). Four respondents did not report any chronic conditions.

One respondent was caring for a bedridden husband. When asked who they considered would take care of them, if necessary, six indicated a daughter; five a spouse; three said their children; one a sister; and two said they did not know who would care for them.

The majority of the respondents reported that they were satisfied with the services of the local health clinics. Although some reported no health problems, the majority had more than one health problem. One respondent reported: "Ek het altyd gesond geleef, maar nou val my moed af" (I always lead a healthy life, but now my courage fails me.)

\section{SOCIAL LIFE AND BONDING SOCIAL CAPITAL}

Interpersonal relationships form a social network that gives the individuals a sense of embeddedness in a community. This constitutes what Woolcock (in Field, 2003:42) refers to as bonding social capital. To determine the ties that respondents have, they were requested to list the contacts that they had on a regular basis.

The collected data revealed the following: social contacts with children were the highest (27), followed by neighbours (24); friends (21); and siblings and in-laws (21). The two respondents 
that had the greatest (5) interaction with children both reported no contact with friends. Several authors refer to research that has found that, despite the prevalence of divorce and other forms of family disorganisation, inter-generational relations between elderly parents and their adult children are both extensive and important to both parties. The exchanges that take place are both tangible and the transfers operate in both directions (Biegel, Magaziner \& Baum, 1991; Wilcox \& Merlin, 1991).

The frequency of contacts were as follows: "often", i.e. on a weekly basis - six times weekly (3); four times (3); eight times (2); seven times (1) and ten times (1). Eight respondents reported that they had contact with certain persons in their social network "sometimes". i.e. once a month.

\section{Organised activities and bridging social capital}

Individuals engage in organised activities with other people when they share a common interest. Woolcock (in Field, 2003:42) refers to this phenomenon as bridging social capital.

The following findings emerged: all the respondents, excluding the chair-bound lady, reported involvement with a church. Religious affiliation was spread over nine different denominations. Ten of the respondents said that they were very involved, i.e. go to church regularly; are office bearers in the church; are members of the mother's union, other church groups or church choir. Five reported that they attend church regularly; and two stated that they sometimes go to church. According to Moody (1998:442), researchers have been interested in the benefits that religion can have for older people. Studies have found a positive correlation between measures of well-being and religious beliefs among the elderly. Those with high levels of religious commitment also have higher levels of life satisfaction than those with no such sense of meaning. Moody (1998:442) states: "This relationship holds even when age, marital status, education and perceived health status are controlled for."

Nine respondents were involved in organised social activities. The Women's League of the ANC has organised a club for the elderly and some of the respondents are members, attend meetings and go on outings. Six respondent reported involvement with political affairs either as registered party members; as an office bearer on a ward committee, or as one respondent said: "as die kar ry en skree ons moet na die 'hall' gaan" (if the car passes and shouts that they have to go to the hall). Three respondents have been going to literacy classes for two years. Two male respondents go to sport events as spectators. One respondent said that they have a "friendship club" in their street. They celebrate each others' birthdays and socialise regularly.

The majority of respondents were involved in organised activities. Putman (2000:280) found that people born in the 1920s belonged to nearly twice as many associations as their grandchildren; were twice as likely to vote; and almost three times as likely to read a newspaper.

\section{SUPPORT NETWORK}

One of the pay-offs of social networks is that they can become support networks. A social network becomes a support network when exchanges take place. The support can be of a concrete nature, or emotional support, or advice and information. The findings are given below.

\section{CONCRETE SUPPORT}

The perceived support that a respondent could expect to receive with concrete tasks is shown in the following table: 
TABLE 4

CONCRETE SUPPORT

\begin{tabular}{|lc|lc|lc|lc|}
\hline Housekeeping & & Cooking & & Shopping & & Transport & \\
\hline Self & 7 & Self & 11 & Self & 8 & Taxi & 13 \\
\hline Self and daughter & 3 & Daughter & 3 & Daughter & 3 & Taxi and family & 1 \\
\hline Daughter & 3 & Self and spouse & 1 & Wife & 2 & Son & 1 \\
\hline Self and spouse & 2 & Self and daughter & 1 & Self and spouse & 1 & Daughter & 1 \\
\hline Spouse & 2 & Shared by household & 1 & Self and daughter & 1 & Nephew & 1 \\
\hline & & & & Son & 1 & & \\
\hline & & & Grandniece & 1 & & \\
\hline
\end{tabular}

It appears that the family is the primary source of social support for older people. According to Hooyman \& Kiyak (1991:298), the marital relationship plays a crucial support function in the majority of older peoples' lives. Spouses are most likely to serve as confidants and to provide support. With the increase in life expectancy, more older partners may end up caring for each other frequently for long periods of time. More wives than husbands provide care (Hooyman $\&$ Kiyak, 1991:301).

Following spouses, adult children are the most important source of support in old age. Hooyman and Kiyak (1991:308) report on research that found 29\% of both primary and secondary caregivers are daughters, $23 \%$ wives, and $20 \%$ more distant female non-relatives, although wives and husbands constitute the majority of the sole or primary caregivers.

Mokone (1999) reports on research that found that spouses and adult daughters made up more than $60 \%$ of the caregivers and husbands only $13 \%$. Daughters were much more likely than sons to be the primary or sole providers of assistance and, if the sons were married, they were involved in decision making whilst their wives provided the actual care.

Wilcox and Merlin (1991) state that the more closely related the caregiver, the greater the amount of help provided. Friends and neighbours are important for socialisation and mutual assistance among well elderly people, but are less involved with impaired elderly people.

\section{FINANCIAL HELP}

The sources from which the respondents expect to receive financial support are shown in the following table:

TABLE 5

SOURCES OF FINANCIAL SUPPORT

\begin{tabular}{|ll|ll|}
\hline Financial support & & Material help & \\
\hline Children & 4 & Children & 5 \\
\hline Daughter & 4 & Daughter & 2 \\
\hline Son & 1 & Son & 2 \\
\hline Son and niece & 1 & Niece and nephew & 1 \\
\hline Niece and nephew & 1 & Spouse & 1 \\
\hline Sister-in-law & 1 & Does not need help & 1 \\
\hline Spouse & 1 & Family & 10 \\
\hline Friend & 1 & Neighbour & 1 \\
\hline Does not need help & 1 & Daughter-in-law & 1 \\
\hline Does not know & 2 & Soup kitchen & 1 \\
\hline & & They borrow from her & 1 \\
\hline
\end{tabular}


Children are the main source of financial support. In the cases where nieces and nephews were relied on for financial support, the respondent usually played a caregiver role for them.

\section{Care in time of illness}

According to the respondents, support would come from the following sources:

$\begin{array}{lllr}\text { Daughter } & 5 & \text { Spouse } & 4 \\ \text { Children } & 3 & \text { Daughter and grandchild } & 1 \\ \text { Granddaughter } & 1 & \text { Sister } & 1 \\ \text { Daughter-in-law } & 1 & \text { Unknown } & 1\end{array}$

\section{EMOTIONAL SUPPORT}

The perceived emotional support that the respondents expect to receive is presented in Table 6.

Friends are often important sources of intimacy, while relatives other than marital partners are usually not. According to Hooyman and Kiyak (1991:321), women in general have more intimate, diverse and intensive friendships than men, who tend to have more acquaintances and who place a higher value on career-oriented activities. For many men their wives are their only confidantes, a fact that may make widowhood devastating for them. In contrast, women tend to satisfy their need for intimacy throughout their lives by establishing close friendships with other women. Adult children are not likely to be chosen as confidants, primarily because of their being from different cohorts, who are at different stages of the life cycle and more likely to produce inequality of exchange (Hooyman \& Kiyak, 1991:321).

\section{TABLE 6}

\section{EMOTIONAL SUPPORT}

\begin{tabular}{|l|c|c|c|}
\hline & Listen to problems & In time of crises & Comforts you \\
\hline Friend & 3 & 2 & 5 \\
\hline Daughter & 3 & & 2 \\
\hline Children & 3 & 3 & 4 \\
\hline Church & 3 & 3 & 2 \\
\hline Spouse & 2 & 4 & \\
\hline Daughter/friend & 1 & & \\
\hline Aunt & 1 & & 2 \\
\hline Neighbour & 1 & 2 & \\
\hline Granddaughter & & 1 & \\
\hline Nephew & & 1 & 1 \\
\hline Sister & & 1 & \\
\hline Son & & & \\
\hline
\end{tabular}

\section{Advice and information}

The sources that the respondents indicated they would rely on for advice and information in certain circumstances are shown in Table 7. 
TABLE 7

SOURCES OF ADVICE AND INFORMATION

\begin{tabular}{|ll|ll|lc|}
\hline \multicolumn{2}{|c|}{ Health matters } & \multicolumn{2}{c|}{ Business matters } & \multicolumn{2}{c|}{ Decision making } \\
\hline A clinic & 4 & Spouse & 3 & Children & 4 \\
\hline Daughter & 3 & Children & 3 & Daughter & 4 \\
\hline Clinic and friend & 2 & Son & 3 & Spouse & 3 \\
\hline Clinic and doctor & 1 & Friend & 3 & Son & 3 \\
\hline Clinic and radio & 1 & Daughter & 2 & Friends & 2 \\
\hline Doctor & 1 & Colleague & 1 & Pastor & 1 \\
\hline Son & 1 & Sister & 1 & & \\
\hline Sister & 1 & Nobody & 1 & & \\
\hline Nurse & 1 & & & & \\
\hline Friend & 1 & & & & \\
\hline Nobody & 1 & & & & \\
\hline
\end{tabular}

It appears that it is only in respect of health matters that the respondents would rely on professionals. There is minimal linking social capital, "which reaches out to unlike people in dissimilar situation such as those who are entirely outside the community thus enabling members to leverage a far wider range of resources than are available within the community" (Woodcock in Field, 2003:42).

\section{CONCLUSION AND RECOMMENDATION}

The findings of this exploratory study revealed that the members of the research group are embedded in their society through a substantial social network. This indicates the presence of bonding social capital in the community. The research group's engagement in organised activities is also high and this points to bridging social capital. Whereas bonding and bridging social capital operate on a horizontal level, i.e. within the primary group (micro level) and the community(meso level), linking capital operates vertically, i.e. it reaches out to resources outside the community (macro level). In terms of linking social capital, the research group showed low levels.

By placing such importance on social capital as a component of social policy, the Department of Social Services and Poverty Alleviation in the Western Cape shows that it wants to cooperate with civil society and that it aims at capacity building through developing the human resources of communities. This building of social capital will help marginalised groups and communities to play a more important role in society and thus to enhance social inclusion.

The present research group of black elderly persons in Kayamandi demonstrated that they are involved in social networks and organised activities. It would therefore be advantageous to use them as a core age cohort to expand social capital in Kayamandi. The first step would be to assist the elderly to realise their goal to establish a subsidised senior service centre. This will empower individuals by assisting them to negotiate with outside resources and thus increase the linking social capital in the community. This will also establish a resource in the community and create a basis for the elderly to reach out and motivate others to become involved. 


\section{BIBLIOGRAPHY}

BEAVER, M.L. \& MILLER, D.A. 1992. Clinical social work practice with the elderly $\left(2^{\text {nd }}\right.$ ed). Belmont, Ca: Wadsworth Publishing Co.

BIEGEL, D.E., MAGAZINER, J. \& BAUM, M. 1991. Social support networks of white and black elderly people at risk for institutionalization. Health and Social Work, 16(4):245-257.

BISCOMBE, H. (red) 2006). In ons bloed. Stellenbosch: Sun Press.

CAPE WINELANDS DISTRICT MUNICIPALITY 2006. Chapter 4, Stellenbosch local municipality.

DEPARTMENT OF SOCIAL SERVICES AND POVERTY ALLEVIATION. 2005. Social Capital Formation Document. Cabinet Lekgotla, 9-10 February 2005.

DE VOS, A.S., STRYDOM, H., FOUCHÉ, C.B. \& DELPORT, C.S.L. 2002. Research at grass roots: for the social sciences and human service professions $\left(2^{\text {nd }} \mathrm{ed}\right)$. Pretoria: Van Schaik Publishers.

FERRARO, K. (ed) 1990. Gerontology. Perspectives and Issues. New York: Springer Publishing Co.

FIELD, J. 2003. Social capital. London: Routledge.

GERMAIN, C.B. \& GITTERMAN, A. 1980. The life model of social work practice. New York, NY: Columbia University Press.

HOLAHAN, C.J., MOOS, R.H., HOLAHAN, C.K. \& BRENNAN, P.L. 1996. Social support, coping strategies, and psychosocial adjustment to cardiac illness: Implications for assessment and Prevention. Journal of Prevention and Intervention in the Community, 13(1/2):33-52.

HOOYMAN, N.R. \& KIYAK, H.A. 1991. Social gerontology: a multidisciplinary perspective. $\left(2^{\text {nd }}\right.$ ed). Boston: Allyn \& Bacon.

HOWES, F. \& GREEN, S. 1996. Buite-egtelike moederskap in die Paarl-Wellingtongebied: die moeder se versorgingspotensiaal en steunstelsel. Raad vir Geesteswetenskaplike Navorsing, Pretoria.

KART, C.S. 1985. The realities of aging. An introduction to gerontology $\left(2^{\text {nd }}\right.$ ed $)$. Boston: Allyn \& Bacon, Inc.

LIN, N. 2001. Social capital: a theory of social structure and action. Cambridge: Cambridge University Press.

MOKONE, J.M. 1999. The role played by the family as a support system for the elderly and the challenges of caregiving. Social Work/Maatskaplike Werk, 35(2):133-137.

MOKONE, J.M. 2006. Challenges experienced by grandparents raising grandchildren: an exploratory study. Social Work/Maatskaplike Werk, 42(2):187-200.

MOODY, H.R. 1998. Aging. Concepts and controversies $\left(2^{\text {nd }}\right.$ ed). Thousand Oaks, Ca.: Pine Forge Press.

MUTRAN, E. \& REITZES, D.C. 1990. Intergenerational exchange relationships in the aging family. In: FERRARO, K. (ed) Gerontology. Perspectives and issues. New York: Springer Publishing Co. 
190

NGHATSANE, D.D.M. 1992. The dynamics of informal support and social service delivery systems in Langa, Guguletu and Khayelitsha. Stellenbosch: University of Stellenbosch. (DPhil)

NORTON, D.G. 1978. The dual perspective: inclusion of ethnic minority content in the social work curriculum. New York: Council of Social Work Education.

PUTNAM, R.D. 2000. Bowling alone. New York, NY: Simon \& Schuster.

SHEAFOR, R.W., HOREJSI, C.R. \& HOREJSI, G.A. 1994. Techniques and guidelines for social work practice. London: Allyn \& Bacon.

STELLENBOSCH MUNICIPALITY INTEGRATED DEVELOPMENT PLAN. 2006. Fourth Annual Review, May.

STRYDOM, H. 2001. Social development and services for disadvantaged older persons in Potchefstroom. Die Maatskaplikewerk-Navorser-Praktisyn/The Social Work PractitionerResearcher, 13(2)98-117.

TRACY, E.M. \& WHITTAKER, J.K. 1990. The social network map: assessing social support in clinical practice. Families in Society, 71(8):461-470.

WARREN, D. 1981. Helping networks. Notre Dame: University of Notre Dame Press.

WILCOX, J. \& MERLIN, A.T. 1991. Informal helpers of elderly home care clients. Health and Social Work, 16(4):258-265.

Dr Francis Howes, Department of Social Work, Stellenbosch University, Stellenbosch, South Africa. 